\title{
Influence of stocking density on the culture potential of endangered riverine catfish Rita rita (Hamilton, 1822) in raceway
}

\author{
MUHAMMAD FORHAD ALI, MD. RAFIQUL ISLAM SARDER, MOHAMMAD MATIUR \\ RAHMAN AND MD. FAZLUL AWAL MOLLAH \\ Department of Fisheries Biology and Genetics, Bangladesh Agricultural University, Mymensingh, Bangladesh \\ e-mail:mforhad.fc@gmail.com
}

\begin{abstract}
Endangered catfish Rita rita were reared in a cemented raceway to evaluate its culture potential at three different stocking densities of 4, 8 and 16 juveniles $\mathrm{m}^{-2}$ under three treatments viz., T1, T2 and T3 respectively, with three replications each. The mean initial length and weight of the juveniles were $20.15 \pm 1.51 \mathrm{~cm}$ and $100.26 \pm 6.57 \mathrm{~g}$, respectively. The fish were reared by providing clean poultry viscera (containing $48.56 \%$ crude protein) at $5-2 \%$ of biomass once a day. Water quality parameters were monitored daily. Growth parameters such as final mean total length, relative length gain, mean body weight, relative weight gain, specific growth rate (SGR) and condition factor were significantly higher $(\mathrm{p}<0.5)$ in $\mathrm{T} 1$. The survival rate was $100 \%$ in all the treatments and the gross and net production of the fish were significantly $(\mathrm{p}<0.5)$ higher in T3 $\left(8.38 \pm 0.04\right.$ and $\left.6.78 \pm 0.004 \mathrm{~kg} \mathrm{~m}^{-2}\right)$ than in T2 $\left(4.49 \pm 0.03\right.$ and $\left.3.69 \pm 0.003 \mathrm{~kg} \mathrm{~m}^{-2}\right)$ and $\mathrm{T} 1(2.36 \pm 0.02$ and $1.96 \pm 0.002$ $\mathrm{kg} \mathrm{m}^{-2}$ ). Though the growth performance of $R$. rita was significantly influenced by the lowest stocking density, the survival rate and production suggest that this species can be reared at a minimum density of 16 juveniles $\mathrm{m}^{-2}$ in cement raceway with suitable environment and adequate supplemental feed.
\end{abstract}

Keywords: Endangered fish, Poultry viscera, Raceway, Rita rita, Stocking density

\section{Introduction}

Rita rita (Hamilton, 1822) a bagrid catfish belonging to the order Siluriformes, is popularly known as 'Rita' in Bangladesh and the Indian subcontinent. It is a highly valued species in Bangladesh. It is one of the giants of its genus, growing to a length of $150 \mathrm{~cm}$ (Talwar and Jhingran, 1991). Generally, it inhabits muddy to clear water (Bhuiyan, 1964) and grows in large rivers (Shaji, 1995) and shallow water of estuaries, haor, baor, beels and brackishwater ecosystems (Mirza, 1982; Talwar and Jhingran, 1991; Rahman, 2005; Yashpal et al., 2006; Siddiqui et al., 2007). It is a potamodromus, bottom and column feeder, usually feeding on insects, molluscs, shrimps, fishes, roots of aquatic plants and also putrid carcass of animals (Bhuiyan, 1964; Rahman, 2005; Siddiqui et al., 2007). The abundance of this fish was reported as very rich in Afghanistan, Pakistan, India, Nepal, Bangladesh and Mayanmar in the past (Tripathi, 1996). Though the fish is harvested from the wild in fairly large quantities annually, its catch is progressively declining due to the collective effect of different factors, such as massive siltation in natural habitats, loss of breeding and nursery grounds, overexploitation, alteration of habitats and ecological modifications like blocking of migratory channels by construction of flood control dams, roads and highways, townships and other developmental infrastructures, irrigation schemes, destructive fishing pressure (IUCN, 2015), aquatic pollution through pesticides and chemicals (Parveen and Faisal, 2002; World Bank, 2005) as well as short term leasing of haor, baor and beels. Consequently, the species has been documented as "Endangered" in Bangladesh (IUCN, 2015), "Near Threatened" in India (Dubey, 1994; CAMP, 1998; Gupta, 2015) and as of "Least Concern" globally (IUCN, 2015). As natural population of the species is declining fast, planners, policy makers, aquaculturists and fishery biologists are thinking of its domestication and cultivation through farming to sustain and augment its production. The fish is very popular for its good taste. Its flesh is rich in protein $(17.22-19.55 \%)$, low in fat $(1.01-2.70 \%)$ and has good amount of minerals $(0.89-1.07 \%)$ compared to other teleosts as well as catfishes (Mitra et al., 2017). Considering its high market demand, the riverine catfish R. rita could be a prospective candidate for aquaculture in Bangladesh and there is an urgent need to establish domestication, cultivation and artificial propagation of the species, to augment the natural population, meet the high demand and help in conservation of the species. Some attempts have been taken to develop culture techniques for the fish, such as induced breeding (Mollah et al., 2008), induced breeding and larval rearing (Taslima and 
Mollah, 2012) and effect of different feeds on growth and survival (Amin et al., 2010). But the influence of stocking density on the production of this important fish is yet to be elucidated.

Stocking density is known to have a profound influence on fish growth, survival, behaviour and production in any aquaculture system, especially in monoculture. Studies have indicated that lower stocking density produced higher weight gain, specific growth rate (SGR), feed conversion ratio (FCR), protein efficiency ratio (PER) and lowest yield in Pangasius sutchi (Azimuddin et al., 1999), higher survival rate and lower yield in case of $P$. pangasius (Razzaque et al., 2003), lowest gross and net yield in P. sutchi (Islam et al., 2006), Clarias gariepinus (Edward et al., 2010) and Mystus gulio (Siddiky et al., 2015), highest mean weight gain, SGR, survival rate and yield in Heteropneustes fossilis (Rahman et al., 2014; Monir and Rahman, 2015) and maximum profit in C. gariepinus (Suleiman and Solomon, 2017). Sometimes excellent fish seed do not execute satisfactory growth except with correct stocking practices (Sanches and Hayashi., 1999). The full utilisation of space for highest fish production through intensive culture can improve the profitability of the fish farm, whereas under-stocking results in failure to maximise possible utilisation of the space, and overstocking can cause stress, which leads to higher energy requirements and causes reduced growth and food utilisation (Leatherland and Cho, 1985). It has also been investigated that fish stocked at higher stocking density generally is associated with problems such as reduction in FCR, condition factor and growth performance (Lymbery, 1992; Ellis et al., 2002; Sanches, 2013). Thus, stocking density is a key factor to total production, farm economics and profitability for fish farming (Watanabe et al., 2002). Identifying the optimum stocking density for a species is therefore a critical factor in designing an efficient aquaculture system. So, the objective of this study was to evaluate the effect of initial stocking density on the growth, survival and yield of the riverine catfish, $R$. rita, in raceway. It is hoped that the results will contribute to some extent to the knowledge of culture requirements of the species.

\section{Materials and methods}

The study was conducted in a raceway system of the Department of Fisheries Biology and Genetics, BAU, Mymensingh. It was conducted for a period of twelve months from January to December 2016.

\section{Collection and stocking of fish}

Juvenile $R$. rita were collected during NovemberDecember, 2015 from the Brahmaputra River near Bangladesh Agricultural University (BAU) campus with the help of fishermen, who caught the fish by berjal and box trap. Juveniles were selected for the study on the basis of good health, bright body colour, uniform length and weight, active movement and absence of injuries and parasites. They were transported to the experimental area in plastic half drums (one juvenile per litre of water) without aeration, using a van and stocked in large cement tanks filled with ground water for acclimatisation. Transportation was done as quickly as possible without any delay, to reduce mortality. Only healthy and active juveniles were released into the tanks that were previously prepared for the experiment. The fish were acclimatised for a period of one week. Length $(\mathrm{cm})$ and weight $(\mathrm{g})$ of each fish was recorded before releasing into the experimental raceway.

\section{Experiment design}

In order to study the growth, survival and production potential, three treatments were used in the experiment, each with three replications. Nine chambers of the experimental raceway were divided into three groups, each group comprising three chambers. The volume of each chamber was $1.83 \mathrm{~m} \times 1.12 \mathrm{~m} \times 1.0 \mathrm{~m}$ cubic meter and the chambers were separated from each other with nylon net attached by means of an iron frame. Juveniles were released in triplicate into the three sets of chambers maintaining a stocking density of 4,8 and 16 nos. $\mathrm{m}^{-2}$, respectively. The initial average length and weight of the fish were $20.15 \pm 1.51 \mathrm{~cm}$ and $100.26 \pm 6.57 \mathrm{~g}$, respectively .

\section{Feeding of fish}

Wet poultry viscera were used as feed for the experiment. The viscera were collected from the local market and cleaned very carefully. The proximate composition of poultry viscera was analysed as per AOAC (2005). The poultry viscera contained $85.45 \%$ dry matter with $48.56 \%$ crude protein, $14.50 \%$ crude lipid and $6.82 \%$ ash. Feed was supplied at $5-2 \%$ of body weight once a day in the afternoon. The amount of feed supplied to T1, T2 and T3 is given in Table 2. Feeding ration was adjusted in accordance with increase in body weight (Hogendoorn and Koops, 1983) and diet allotments were increased monthly depending on the growth. The leftover feed particles were siphoned out after 30 min of feed supply.

\section{Water quality monitoring}

Temperature was measured using mercury glass bulb thermometer. Dissolved oxygen was monitored using a dissolved oxygen meter (Hanna, Romania) and $\mathrm{pH}$ with a portable $\mathrm{pH}$ meter (Milwaukee, Romania). To maintain the water quality, waste products were siphoned out with rubber hose daily in the morning, 30\% water was exchanged every alternate day and the tanks 
were completely drained out at monthly intervals, when the fish were removed for growth measurements. Diluted lime was spread on the bottom and side walls of the raceway and left for about an hour, after which the tanks were cleaned before restocking the fish.

Fish growth, survival and production evaluation

The experimental fish were sampled at monthly intervals. Total length of juvenile catfish in different treatments was recorded using fish measuring board to the nearest $0.01 \mathrm{~cm}$ and the weight was determined using an electronic balance (Bel, Italy) to the nearest $0.01 \mathrm{~g}$. The following parameters were then estimated:

Length gain $(\mathrm{cm})=\mathrm{L}_{2}-\mathrm{L}_{1}$,

where, $\mathrm{L}_{2}$ is final total length $(\mathrm{cm})$ and $\mathrm{L}_{1}$ is initial total length $(\mathrm{cm})$ over a sampling period.

Relative length gain $(\mathrm{RLG})(\%)=\{$ Length gain by fish $(\mathrm{cm}) /$ Initial length $(\mathrm{cm})\} \times 100$

Weight gain $(\mathrm{g})=\mathrm{W}_{2}-\mathrm{W}_{1}$,

where $\mathrm{W}_{2}$ is final weight $(\mathrm{g})$ and $\mathrm{W}_{1}$ is initial weight (g) over a sampling period.

Relative weight gain $(\mathrm{RWG})(\%)=\{$ Weight gain by fish (g)/Initial body wt (g)\} x 100

Specific growth rate $(\mathrm{SGR})=\left(\mathrm{LnW}_{2}-\mathrm{LnW}_{1}\right) / \mathrm{T} \times 100$, (Hepher, 1988), where $\mathrm{Ln}=$ Natural $\log , \mathrm{W}_{2}=$ Final mean weight, $\mathrm{W}_{1}=$ Initial mean weight and $\mathrm{T}=$ Time interval.

Condition factor $(\mathrm{K})=100 \mathrm{~W} / \mathrm{L}^{3}$ (Bagenal, 1978), where $\mathrm{W}=$ Final weight $(\mathrm{g}), \mathrm{L}=$ Final standard length (cm).

Survival rate $(\%)(\mathrm{S})=\mathrm{N}_{2} 100 / \mathrm{N}_{1}$ (Fasakin et al., 2001), where $N_{2}=$ Final number of fish at the end of experiment and $\mathrm{N}_{1}=$ Initial number of fish at the beginning of experiment.

$$
\text { Production }(\mathrm{kg})=\{\text { Final mean weight }(\mathrm{g}) \times \text { Number }
$$
of fish survived $\} / 1000$

\section{Statistical analysis}

All the data collected were subjected to analysis using Analysis of variance (ANOVA). Standard deviation was calculated to identify the range of means. Duncan's multiple range test (DMRT) was used to determine the level of significance among treatments (Duncan, 1955).

\section{Results}

\section{Water quality parameters}

As the chambers of raceway in all the treatments are separated only by nylon net, the water quality parameters were found similar and within permissible range in all treatments (Table 1).

Growth performance, survival and production of $R$. rita

There was a decreasing trend of growth in terms of mean length $(\mathrm{cm})$ and weight $(\mathrm{g})$ increment when stocking density was increased (Fig. 1 and 2). The summary of growth indices, survival and production are presented in Table 2.

Length gain

A significant difference $(\mathrm{p}<0.05)$ was observed in final total length of $R$. rita at different stocking densities in different treatments (Table 2). For mean final total length (MFTL), mean length gain (MLG) and relative length gain (RLG), all the treatments were significantly different $(\mathrm{p}<0.05)$ from each other. Treatment-1 (T1) with stocking density of 4 fish $\mathrm{m}^{-2}$ gave the highest MFTL of $34.19 \pm 0.11$ $\mathrm{cm}$ followed by $32.29 \pm 0.12 \mathrm{~cm}$ in T2 stocked with 8 fish $\mathrm{m}^{-2}$ and $30.83 \pm 0.12 \mathrm{~cm}$ in $\mathrm{T} 3$ stocked with the density

Table 1 . Water quality parameters recorded (Mean $\pm \mathrm{SD}$ ) during the experimental period

\begin{tabular}{llll}
\hline \multirow{2}{*}{ Months } & \multicolumn{3}{c}{ Parameters } \\
\cline { 2 - 4 } & Temperature $\left({ }^{\circ} \mathrm{C}\right)$ & Dissolved oxygen $\left(\mathrm{mg} \mathrm{l}^{-1}\right)$ & $\mathrm{pH}$ \\
\hline Jan. & $20.75 \pm 65$ & $5.43 \pm 0.33$ & $7.63 \pm 0.08$ \\
Feb. & $22.75 \pm 65$ & $6.40 \pm 0.33$ & $7.85 \pm 0.11$ \\
Mar. & $25.00 \pm 0.91$ & $5.93 \pm 0.36$ & $8.25 \pm 0.11$ \\
Apr. & $27.28 \pm 0.81$ & $6.38 \pm 0.75$ & $8.58 \pm 0.15$ \\
May & $28.80 \pm 0.50$ & $6.56 \pm 0.43$ & $8.65 \pm 0.11$ \\
Jun. & $29.85 \pm 0.44$ & $6.75 \pm 0.65$ & $8.60 \pm 0.12$ \\
Jul. & $30.00 \pm 0.44$ & $5.83 \pm 0.24$ & $8.22 \pm 0.15$ \\
Aug. & $29.02 \pm 0.68$ & $6.73 \pm 0.80$ & $8.50 \pm 0.22$ \\
Sept. & $28.55 \pm 0.42$ & $7.10 \pm 0.68$ & $8.53 \pm 0.15$ \\
Oct. & $27.63 \pm 0.75$ & $6.02 \pm 0.29$ & $8.48 \pm 0.13$ \\
Nov. & $25.50 \pm 1.29$ & $5.88 \pm 0.33$ & $8.25 \pm 0.18$ \\
Dec. & $23.50 \pm 1.29$ & $5.55 \pm 0.25$ & $7.93 \pm 0.26$ \\
\hline
\end{tabular}




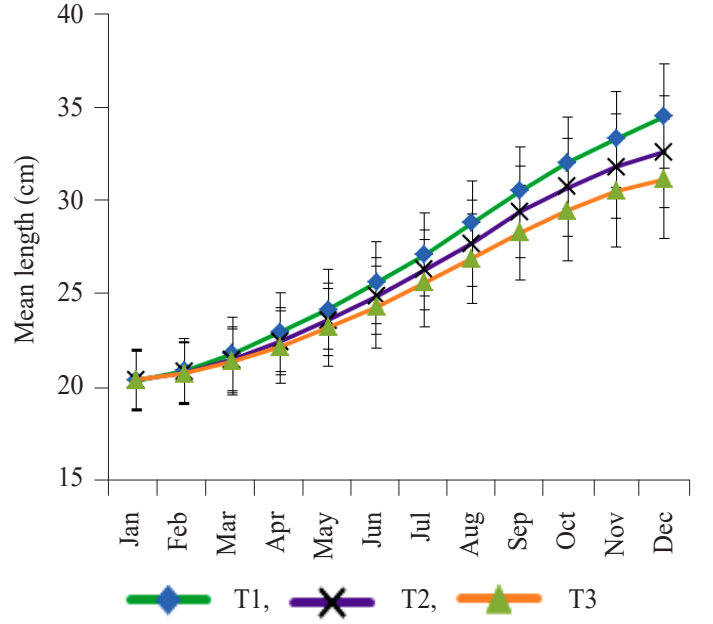

Fig. 1. Monthly mean length increment of $R$. rita cultured in raceway at various stocking densities during the experimental period

of 16 fish $\mathrm{m}^{-2}$. The highest $(\mathrm{p}<0.05)$ MLG of $14.08 \pm 0.11$ $\mathrm{cm}$ was observed in T1 followed by $12.14 \pm 0.11 \mathrm{~cm}$ in T2 and $10.67 \pm 0.1 \mathrm{~cm}$ in T3. Similarly, maximum RLG of $69.96 \pm 0.64 \%$ was recorded in $\mathrm{T} 1$ followed by $60.26 \pm 0.58 \%$ in T2 and $52.92 \pm 0.48 \%$ in T3 (Table 2).

Weight gain

The mean final body weight of the fish at different stocking densities showed significant differences $(p<0.05)$ among the treatments (Table 2). The highest final body weight of $590.50 \pm 0.50 \mathrm{~g}$ was observed in T1 followed by $561.63 \pm 0.40 \mathrm{~g}$ per fish in T2. The lowest body weight

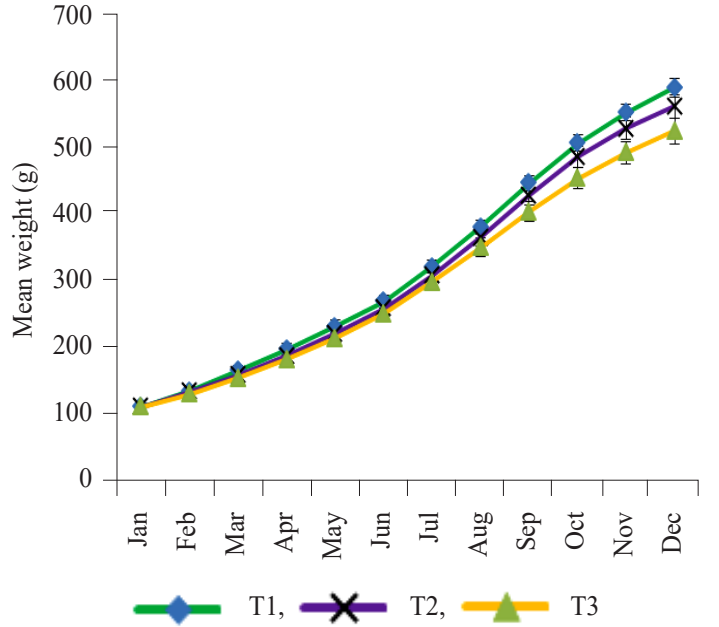

Fig. 2. Monthly mean weight increment of $R$. rita cultured in raceway at various stocking densities during the experimental period

of $523.77 \pm 0.25 \mathrm{~g}$ was recorded in T3. Similarly, the highest weight gain of $490.28 \pm 0.48 \mathrm{~g}$ was obtained in $\mathrm{T} 1$ followed by $461.39 \pm 0.39 \mathrm{~g}$ in $\mathrm{T} 2$ and $423.50 \pm 0.25 \mathrm{~g}$ in T3. When the relative weight gain was analysed, a significant $(\mathrm{p}<0.05)$ effect of stocking density was observed among the treatments. The highest relative weight gain (RWG) of $489.21 \pm 0.38 \mathrm{~g}$ was obtained in $\mathrm{T} 1$ followed by $460.28 \pm 0.35$ in $\mathrm{T} 2$ and $422.36 \pm 0.25 \mathrm{~g}$ in $\mathrm{T} 3$.

\section{Specific growth rate $(S G R)$}

The SGR of $R$. rita juveniles grown for 12 months in raceway at different stocking densities showed significant

Table 2. Growth performance of $R$. rita in raceway at various stocking densities during the experimental period

\begin{tabular}{llll}
\hline Parameters & T1 & T2 & T3 \\
\hline Stocking density (juveniles m ${ }^{-2}$ ) & 4 & 8 & 16 \\
MITL (cm per fish) & $20.12 \pm 1.62$ & $20.15 \pm 1.51$ & $20.17 \pm 1.61$ \\
MFTL (cm per fish) & $34.19 \pm 0.11^{\mathrm{a}}$ & $32.29 \pm 0.12^{\mathrm{b}}$ & $30.83 \pm 0.12^{\mathrm{c}}$ \\
MLG (cm per fish) & $14.08 \pm 0.11^{\mathrm{a}}$ & $12.14 \pm 0.11^{\mathrm{b}}$ & $10.67 \pm 0.10^{\mathrm{c}}$ \\
RLG (\% per fish) & $69.96 \pm 0.64^{\mathrm{a}}$ & $60.26 \pm 0.58^{\mathrm{b}}$ & $52.92 \pm 0.48^{\mathrm{c}}$ \\
MIBW (g per fish) & $100.22 \pm 6.70$ & $100.24 \pm 6.53$ & $100.27 \pm 6.95$ \\
MFBW (g per fish ) & $590.50 \pm 0.50^{\mathrm{a}}$ & $561.63 \pm 0.40^{\mathrm{b}}$ & $523.77 \pm 0.25^{\mathrm{c}}$ \\
MWG (g per fish ) & $490.28 \pm 0.48^{\mathrm{a}}$ & $461.39 \pm 0.39^{\mathrm{b}}$ & $423.50 \pm 0.25^{\mathrm{c}}$ \\
RWG (\% per fish) & $489.21 \pm 0.38^{\mathrm{a}}$ & $460.28 \pm 0.35^{\mathrm{b}}$ & $422.36 \pm 0.25^{\mathrm{c}}$ \\
SGR (\% per day) & $0.49 \pm 0.05^{\mathrm{a}}$ & $0.47 \pm 0.06^{\mathrm{b}}$ & $0.45 \pm 0.08^{\mathrm{c}}$ \\
FCR & $1.39 \pm 0.10^{\mathrm{c}}$ & $1.41 \pm 0.14^{\mathrm{b}}$ & $1.46 \pm 0.18^{\mathrm{a}}$ \\
Condition factor (K) & $1.48 \pm 0.02^{\mathrm{a}}$ & $1.67 \pm 0.02^{\mathrm{b}}$ & $1.79 \pm 0.02^{\mathrm{c}}$ \\
Survival rate $(\%)$ & $100^{\mathrm{a}}$ & $100^{\mathrm{a}}$ & $100^{\mathrm{a}}$ \\
Feed used (kg m ${ }^{-2}$, Dry matter basis) $_{\text {G }}$ & $2.72 \pm 0.01^{\mathrm{c}}$ & $5.21 \pm 0.01^{\mathrm{b}}$ & $9.89 \pm 0.02^{\mathrm{a}}$ \\
Gross production $\left(\mathrm{kg} \mathrm{m}^{-2}\right)$ & $2.36 \pm 0.02^{\mathrm{c}}$ & $4.49 \pm 0.03^{\mathrm{b}}$ & $8.38 \pm 0.04^{\mathrm{a}}$ \\
Net production $\left(\mathrm{kg} \mathrm{m}^{-2}\right)$ & $1.96 \pm 0.002^{\mathrm{c}}$ & $3.69 \pm 0.003^{\mathrm{b}}$ & $6.78 \pm 0.004^{\mathrm{a}}$
\end{tabular}

All values are reported as mean \pm SE. Values in the same row having different superscripts are significantly different $(\mathrm{p}<0.05)$ MITL: Mean initial total length; MFTL: Mean final TL; MLG: Mean length gain; RLG: Relative length gain; MIBW: Mean initial body weight; MFBW: Mean final body weight; MWG: Mean weight gain; RWG: Relative weight gain 
difference $(\mathrm{p}<0.05)$ among the treatments (Table 2). The finest SGR of $0.49 \pm 0.05 \%$ was found in $\mathrm{T} 1$, followed by $0.47 \pm 0.06$ in $\mathrm{T} 2$ and $0.45 \pm 0.08 \%$ in $\mathrm{T} 3$.

\section{Food conversion ratio $(F C R)$}

The FCR estimated at various stocking densities of the riverine catfish reared in the raceway showed a significant difference $(\mathrm{p}<0.05)$ among the treatments (Table 2). The highest FCR of $1.46 \pm 0.18$ was recorded in $\mathrm{T} 3$ followed by $1.41 \pm 0.14$ in $\mathrm{T} 2$ and $1.39 \pm 0.10$ in $\mathrm{T} 1$.

\section{Condition factor $(K)$}

The condition factor of the catfish stocked at various densities in the raceway demonstrated significant differences $(p<0.05)$ among the treatments (Table 2$)$. The highest condition factor of $1.79 \pm 0.02$ was recorded in T3 followed by $1.67 \pm 0.02$ in $\mathrm{T} 2$ and $1.48 \pm 0.02$ in $\mathrm{T} 1$.

\section{Survival rate and production}

There was no difference in survival rate among the treatments at various stocking densities and the survival rate was $100 \%$ in each treatment (Table 2). However, a significant difference $(\mathrm{p}<0.5)$ in production of $R$. rita at different stocking densities was observed (Table 2). The highest gross and net production of $8.38 \pm 0.04$ and $6.78 \pm 0.004 \mathrm{~kg} \mathrm{~m}^{-2}$ were obtained in $\mathrm{T} 3$ followed by $4.49 \pm 0.03$ and $3.69 \pm 0.003 \mathrm{~kg} \mathrm{~m}^{-2}$ in T2 and $2.36 \pm 0.02$ and $1.96 \pm 0.002 \mathrm{~kg} \mathrm{~m}^{-2}$ in $\mathrm{T} 1$.

\section{Discussion}

Water temperature, dissolved oxygen (DO) and $\mathrm{pH}$ estimated during the experimental period were within the acceptable ranges as recommended for tropical aquaculture (Viveen et al., 1985; Beveridge, 1996 ). The water quality parameters recorded in this study conform to the recommendations suggested for other catfish (Ajani et al., 2015). With regular monitoring of water quality, it was ensured that stocking density was the only variable between the three treatments.

Stocking density plays a vital role in the growth and survival of fish in any fish culture operation (Weatherley, 1976; Rahman and Verdegem, 2010). In intensive aquaculture, stocking density is an important indicator that determines the economic feasibility of the production system (Papst et al., 1992). Increase in stocking density results in rising stress, leading to higher energy requirements, causing a reduction in food utilisation and growth rate (Suziki et al., 2001). The present study provides pioneer evidence on the effects of stocking density on growth, survival and production of $R$. rita. There are no previous studies comparing the effects of stocking density on growth, survival and production of $R$. rita, in any aquaculture system. In this study, growth among the Rita juveniles was found to be inversely related to stocking density; i.e. fish grown at lower density attained the highest length and weight gain. The length and weight gain were significantly different $(\mathrm{p}<0.5)$ among the treatments. This finding was similar to that of P. pangasius in ponds (Razzaque et al., 2003), P. sutchi in cages (Azimuddin et al., 1999; Islam et al., 2006), Dutch Clarias juveniles in out-door happas (Sogbesan et al., 2009), C. gariepinus in concrete tanks (Edward et al., 2010) and Heterobranchus bidorsalis (+) $\mathrm{x} C$. gariepinus (ठ) hybrid juveniles in three different culture tanks made of concrete, metal and plastic (Oguguah et al., 2011). Significant reduction in weight was also observed with increasing stocking rates (Olivier and Kaiser, 1997; Hossain et al., 1998). The RLG of R. rita (52.92-69.96\%) was comparatively lower than that observed in C. gariepinus (113.64-136.00\%) cultured in concrete tanks (Edward et al., 2010) and H. bidorsalis x C. gariepinus hybrid catfish (561.72-744.78\%) in concrete tanks (Oguguah et al., 2011). The RWG of Rita catfish (422.36-489.21\%) was relatively lower than that of P. pangasius (555.12-963.02\%) in ponds (Razzaque et al., 2003), H. bidorsalis x C. gariepinus hybrid catfish (563.09-775.18\%) in concrete tanks (Oguguah et al., 2011) and P. sutchi (1526.56-2259.70\%) in net cages (Azimuddin et al., 1999), but higher than that of C. gariepinus $(77.30-330.50 \%)$ and Heterobranchus longifilis (129.92-210.23\%) in ponds (Toko et al., 2007) and C. gariepinus (123.07-134.27\%) reared in concrete tanks (Edward et al., 2010).

Highest SGR was recorded in lowest stocking density of Rita; the value decreased with the increase of stocking density and was significantly different among the treatments $(\mathrm{p}<0.5)$. A similar trend of SGR was reported in P. sutchi in cages (Azimuddin et al., 1999), C. macrocephalus in cages (Bombeo et al., 2002), Dutch Clarias juveniles in out-door hapas (Sogbesan et al., 2009), C. gariepinus in concrete tanks (Edward et al., 2010) and in aquaria (Ajani et al., 2015). The SGR of Rita (0.45-0.49) was comparatively higher than that of Dutch Clarias (0.23-0.35) in out-door hapas (Sogbesan et al., 2009) and lower than that of H. fossilis (1.06-1.23) in earthen ponds (Rahaman et al., 2014) and P. bocourti (2.04-2.38) in cages (Jiwyam, 2011).

The FCR values obtained from feeding of cleaned and chopped poultry viscera (containing $48.56 \%$ crude protein) in this study were satisfactory. FCR was directly related to the stocking density i.e., lowest FCR was observed in lowest stocking density and the value was significantly different $(\mathrm{p}<0.5)$ among the treatments. Thus, feed intake increased with the increase of stocking density. This indicated that feed conversion was more efficient 
when competition was less. This FCR (1.39-1.46) was higher than the FCR reported in Dutch Clarias juveniles (0.06-0.17) reared with formulated pellet feed containing $45 \%$ crude protein (Sogbesan et al., 2009) and C. gariepinus (1.01-1.40) fed with commercial diet containing $45 \%$ crude protein (Ajani et al., 2015); similar to that of hybrid catfish (C. gariepinus $\mathrm{x} H$. longifiliis) (1.28-1.60) fed with commercial diet (Ofor and Afia, 2015 ) and lower than that of other catfishes like P. bocourti (1.54-1.98) fed with commercial pellet feed containing $40 \%$ crude protein (Jiwyam, 2011), P. sutchi (1.73-2.04) reared with an experimental diet containing $35 \%$ protein (Azimuddin et al., 1999) and P. pangasius (7.06-7.72) provided with farm-made feed (Razzaque et al., 2003).

The mean condition factor illustrated that fish in all the treatments were in good condition throughout the experimental period. The condition factor obtained in this study was above 1.0, indicating that the feeds were properly utilised for good growth and production. This finding conforms to the results obtained with $C$. gariepinus (Edward et al., 2010).

The survival rate recorded in this study was $100 \%$ in all stocking densities after one year culture period and it was not affected by stocking density. The high survival rate may be attributed to proper handling and feeding of fish and possibly good water quality parameters. The survival rate of $P$. hypophthalmus in cemented tanks was also not clearly influenced by stocking density (Malik et al., 2014). This was also in agreement with the results of cage culture of sutchi catfish P. sutchi (Rahman et al., 2006), African catfish C. gariepinus and vundu catfish H. longifilis (Toko et al., 2007), Asian river catfish P. bocourti (Jiwyam, 2011) and C. gariepinus (Dasuki et al., 2013). The survival rate of Rita (100\%) was similar to that of C. gariepinus $(100 \%)$ and $H$. longifilis (96.7 - 100\%) cultured in ponds (Toko et al., 2007) and was higher than that of many other catfishes such as hybrid catfish C. gariepinus x H. longifilis (37-59\%) reared in tanks (Ofor and Afia, 2015), M. gulio (50.17-64.41\%) reared in earthen ponds (Siddiky et al., 2015), C. gariepinus (70 80\%) reared in concrete tanks (Edward et al., 2010) and $H$. fossilis $(71-87 \%)$ reared in farmer's ponds (Kohinoor et al., 2012) with varying stocking densities of all the catfishes.

It was observed that the riverine catfish $R$. rita did not survive in earthen ponds, and they have better growth and survival in concrete raceways, cisterns and tanks (Md. Rafiqul Islam Sarder, per. comm.). It is easy to maintain improved water quality and ensure proper feeding, grading, precise disease treatments, collection of fish wastes and harvesting of fish in raceway culture system (Masser and Lazur, 1997) and that is why the present experiment was conducted in concrete raceway.

In the present study, though the best individual growth, both in length $(14.08 \pm 0.11 \mathrm{~cm})$ and weight $(490.28 \pm 0.48 \mathrm{~g})$ of fish was observed in T1 at the stocking density of 4 fish $\mathrm{m}^{-2}$, the highest gross and net production $(8.38 \pm 0.04$ and $6.78 \pm 0.004 \mathrm{~kg} \mathrm{~m}^{-2}$ ) was obtained in $\mathrm{T} 3$ at the stocking density of $16 \mathrm{fish} \mathrm{m}^{-2}$. It is clear from the results that both production and yield increased with increase of stocking density. Results of the study are strongly supported by the results of studies in riverine catfish $P$. pangasius in net cages (Sarder and Mollah, 1991) and in earthen ponds (Razzaque et al., 2003), sutchi catfish P. sutchi in cage aquaculture (Islam et al., 2006), African catfish, C. gariepinus reared in concrete tanks (Edward et al., 2010), Asian river catfish $P$. bocourti cultured in cages (Jiwyam, 2011) and nona tengra $M$. gulio cultured in earthen ponds (Siddiky et al., 2015). While the net production of $R$. rita (1.96-6.78 $\left.\mathrm{kg} \mathrm{m}^{-2} \mathrm{yr}^{-1}\right)$ was quite higher than the yield of M. gulio $\left(0.13-0.19 \mathrm{~kg} \mathrm{~m}^{-2} \mathrm{yr}^{-1}\right)$ at a density of 8-16 fry $\mathrm{m}^{-2}$ in earthen ponds (Siddiky et al., 2015), C. gariepinus $\left(0.31-2.28 \mathrm{~kg} \mathrm{~m}^{-2} \mathrm{yr}^{-1}\right)$ and $H$. longifilis $(0.61-1.51 \mathrm{~kg}$ $\left.\mathrm{m}^{-2} \mathrm{yr}^{-1}\right)$, both at density of 4-8 juvenile $\mathrm{m}^{-2}$ in ponds (Toko et al., 2007) and H. fossilis (1.51-1.81 $\mathrm{kg} \mathrm{m}^{-2} \mathrm{yr}^{-1}$ ) at stocking density of $12.5-25$ fry $\mathrm{m}^{-2}$ in farmer's ponds (Kohinoor et al., 2012). It was similar to the production of P. sutchi (3.00-6.70 $\left.\mathrm{kg} \mathrm{m}^{-2} \mathrm{yr}^{-1}\right)$ with rearing density of 60-150 fish $\mathrm{m}^{-2}$ in cages suspended in a river channel (Islam et al., 2006) and fairly lower than the production of C. gariepinus (4.08 - $8.51 \mathrm{~kg} \mathrm{~m}^{-2} \mathrm{yr}^{-1}$ ) at stocking density of 5-10 fish $\mathrm{m}^{-2}$ fed with chicken viscera in earthen ponds (Abou et al., 2016), C. gariepinus (4.00-10.00 kg m-2 $\mathrm{yr}^{-1}$ ) in ponds with $25 \%$ water exchange per day (Hecht et al., 1988) and Pangasianodon hypophthalmus (7 - $85 \mathrm{~kg} \mathrm{~m}^{-2} \mathrm{yr}^{-1}$ ) with stocking density of 18-125 fish $\mathrm{m}^{-2}$ in ponds (Phan et al., 2009).

This study suggests that $R$. rita can be cultured at high densities in raceway system provided that suitable physical, environmental and nutritional conditions are met. As the stocking density has significant effects on production, higher densities may be used to obtain higher biomass and to increase farm profitability. While the final harvest and production values are directly related to stocking density, there will be a density at which mortality would be lower, growth would be higher and production would increase. This critical point was not examined in the present experiment and the highest stocking density was maintained as 16 fish $\mathrm{m}^{-2}$. Further studies are required to establish the optimum stocking density for the riverine catfish cultured in the raceway system, which would 
help fish farmers to produce fish of desirable size with maximum profit.

\section{Acknowledgments}

The authors are grateful to the UGC-World Bank for providing financial assistance to carry out this research under the research project HEQEP-AIF, CP-3050.

\section{References}

Abou, Y., Oke, V. and Odountan H. O. 2016. Effects of stocking density on growth, production and farming profitability of African catfish Clarias gariepinus (Burchell, 1822) fed chicken viscera-diet in earthen ponds. Int. J. Biosci., 6(6): 404-414. doi.org/10.12692/ijb/9.6.404-414.

Ajani, E. K., Orisasona, O. and Jenyo-Oni, A. 2015. Growth and economic performance of Clarias gariepinus fry reared at various stocking densities. J. Fish. Livest. Prod., 3: 136. doi.10.4172/2332-2608.1000136.

Amin, M. R., Mollah, M. F. A., Ali, M. R. and Nahiduzzaman, M. 2010. Effects of different feed items on the growth and survival of endangered riverine catfish Rita rita (Hamilton). Univ. J. Zool. Rajshahi Univ., 28: 11-14. DOI: 10.3329/ ujzru.v28i0.5279.

AOAC 2005. Official methods of analysis, $14^{\text {th }}$ edn. Association of Official Analytical Chemists (AOAC), Arlington, VA, USA.

Azimuddin, K. M., Hossain, M. A., Wahab, M. A. and Noor, J. 1999. Effect of stocking density on the growth of Thai pangas, Pangasius sutchi (Fowler) in net cage fed on formulated diet. Bangladesh J. Fish. Res., 3(2): 173-180.

Bagenal, T. B. 1978. Methods of assessment of fish production in freshwater, Handbook No. 3. Blackwell Science publication Oxford IBP, $35 \mathrm{pp}$.

Beveridge, M. C. M. 1996. Cage aquaculture, $2^{\text {nd }}$ edn. Fishing News, Oxford, $346 \mathrm{pp}$

Bhuiyan, A. L. 1964. Fishes of Decca. Asiatic Society of Pakistan, Publ. No. 13, Decca, 148 pp.

Bombeo, R. F., Fermin, A. C. and Tan-Fermin, J. D. 2002. Nursery rearing of Asian catfish Clarias marcocephalus (Gunther), at different stocking densities in cages suspended in tanks and ponds. Aquac. Res., 33: 1031-1036. doi.org/10.1046/ j.1365-2109.2002.00763.x.

CAMP 1998. Conservation assessment and management plan (C.A.M.P.) In: Molur, S. and Walker, S. (Eds.), Freshwater fishes of India, Workshops Report 1998. 22-26 September 1997, Lucknow, India, 156 pp.

Dasuki, A., Auta, J. and Oniye, S. J. 2013. Effects of stocking density on production of C. gariepinus juveniles in floating bamboo cages at Kubanni Reservior, Zaria, Nigeria, BAJOPAS, 6(1): 112-117. http://dx.doi.org/10.4314/bajo pas.v6i1.23.
Dubey, G. P. 1994. Endangered, vulnerable and rare fishes of west coast of India. Threatened fishes of India, Proceedings of the National seminar on endangered fishes of India. National Bureau of Fish Genetic Resources, Allahabad, p. 77-95.

Duncan, D. B. 1955. Multiple range and multiple $F$ tests Biometrics, 11: 1-42. DOI: 10.2307/3001478.

Edward, A., Ladu, B. M. B. and Elihu, A. 2010. Growth, survival and production economics of Clarias gariepinus fingerlings at different stocking densities in concrete tanks. Afr. J. Gen. Agric., 6(2): 59-66.

Ellis, T., North, B., Scott, A. P., Bromage, N. R., Porter, M. and Gadd, D. 2002. The relationship between stocking density and welfare in farmed rainbow trout. J. Fish. Biol., 61: 493-531. doi.org/10.1111/j.1095-8649.2002.tb00893.x.

Fasakin E. A., Balogun, A. M. and Fagbenro, O. A. 2001: Evaluation of sun-dried water fern, Azolla africana and Duckweed, Spirodela polyrrhiza, in practical diets for Nile tilapia, Oreochromis niloticus fingerlings. J. Appl. Aquac., 11(4): 83-92. doi.org/10.1300/J028v11n04_09.

Gupta, S. 2015. Rita rita (Hamilton, 1822), a threatened fish of Indian subcontinent. Int. Res. J. Biol. Sci., 4(11): 70-73.

Hecht, T., Uys, W. and Britz, P. J. 1988. The culture of sharptooth catfish Clarias gariepinus in southern Africa. South African National Scientific Programmes Report No. 153, 133 pp.

Hepher, B. 1988. Nutrition of pond fishes. Cambridge University Press, UK, 388 pp.

Hogendoorn, H. and Koops, W. J. 1983. Growth and production of African catfish Clarias lazera (C. \& V.). Effects of stocking density, pond size and mixed culture with tilapia (Sarotherodon niloticus L.) under extensive field condition. Aquaculture, 32(1783): 253-263.

Hossain, M. A. R., Beveridge, M. C. M. and Haylor, G. S. 1998. The effects of density, light and shelter on the growth and survival of African catfish (Clarias gariepinus Burchell, 1822) fingerlings. Aquaculture, 160: 251-258. DOI: 10.101 6/S0044-8486(97)00250-0.

Islam, M. S., Rahman, M. M. and Tanaka, M. 2006. Stocking density positively influences the yield and farm profitability in cage aquaculture of sutchi catfish, Pangasius sutchi. J. Appl. Ichthyol., 22: 441-445. DOI: 10.1111/j.1439-0426. 2006.00746.x.

IUCN 2015. Red list of Bangladesh, vol. 5: Freshwater fishes. International Union for Conservation of Nature (IUCN), Bangladesh Country Office, Dhaka, Bangladesh, xvi+ $360 \mathrm{pp}$.

Jiwyam, W. 2011. The effect of stocking density on yield, growth and survival of Asian river catfish (Pangasius bocourti Sauvage, 1880) cultured in cages. Aquac. Int., 19: 987-997. DOI: 10.1007/s10499-011-9416-1. 
Kohinoor, A. H. M., Khan, M. M., Yeasmine, S., Mandol, P. and Islam, M. S. 2012. Effects of stocking density on growth and production performance of indigenous stinging catfish, Heteropneustes fossilis (Bloch). Int. J. Agr. Res. Innov. Tech., 2(2): 9-14.

Leatherland, J. F. and Cho, C. Y. 1985. Effect of rearing density on thyroid and internal gland activity and plasma and hepatic metabolite levels in rainbow trout, Salmo gairdneri, Richardson. J. Fish. Biol., 27: 583-592. doi.org/10.1111/j.1095-8649.1985.tb03203.x.

Lymbery, P. 1992. The welfare of farmed fish, Comparison in world farming. Petersfield, Hampshire.

Malik, A., Kalhoro, H. Shah, S. A. and Kalhoro, I. B. 2014. The effect of different stocking densities on growth, production and survival rate of pangas (Pangasius hypophthalmus) fish in cemented tanks at fish hatchery Chilya Thatta, Sindh-Pakistan. IJIMS, 1(10): 129-136.

Masser, M. P. and Lazur, A. 1997. In-Pond Raceways. SRAC Publication No. 170. Southern Regional Aquaculture Center (SRAC), Auburn University and University of Florida, USA.

Mirza, M. R. 1982. A contribution to the fishes of Lahore. Polymer Publications, Urdu Bazar, Lahore, 48 pp.

Mitra, T., Ganguly, S., Banerjee, S., Mahanty, A., Raman, R. K., Bhowmick S. and Mohanty, B. P. 2017. Nutritional composition of different size groups of catfish Rita rita (Hamilton, 1822) from river Ganga. Indian J. Fish., 64: 68-74. DOI: 10.21077/ijf.2017.64.special-issue.76205-10.

Mollah, M. F. A., Amin, M. R., Sarowar, M. N. and Muhammadullah 2008. Induced breeding of the riverine catfish Rita rita. J. Bangladesh Agril. Univ., 6(2): 361-366. DOI: https://doi.org/10.3329/jbau.v6i2.4835.

Monir, M. S. and Rahman, S. 2015. Effect of stocking density on growth, survival and production of shing (Heteropneustes fossilis) fingerlings under nursery ponds in Northern region of Bangladesh. IJFAS, 2(3): 81-86.

Ofor, C. O. and Afia O. E. 2015. Effect of stocking densities on growth and feed utilisation of hybrid catfish (Clarias gariepinus $\mathrm{x}$ Heterobranchus longifilis) fed at $1 \%$ body weight. Am. J. Biol. Life Sci., 3(6): 211-217.

Oguguah N. M., Nwadukwe, F., Atama, C. I., Chidobem, J. I. and Eyo, J. E. 2011. Growth performance of hybrid catfish (Heterobranchus bidorsalis (†) x Clarias gariepinus $(\widehat{\bigcirc})$ ) at various stocking densities in varied culture tanks. Anim. Res. Int., 8(3): 1419-1430.

Olivier, A. and Kaiser, H. 1997. A comparison of growth, survival rate and number of swordtails Xiphophorus helleri Henkel (Family: Poeciliidae), between two types of culture systems. Aquac. Res., 28(3): 217-221. doi.org/10.1046/j.1365-2109.1997.t01-1-00851.x.

Papst, M. H., Dick, T. A., Arnason, A. N. and Engel, C. E. 1992. Effect of rearing density on the early growth and variation in growth of juvenile Arctic charr, Salvelinus alpines (L.). Aquacu. Fish. Manag., 23: 41-47.

Parveen, S. and Faisal, I. M. 2002. People versus power: the Geopolitics of Kaptai Dam in Bangladesh. Int. J. Water Res. Dev., 18: 197-208. doi.org/10.1080/07900620220121756

Phan, L. T., Bui, T. M., Nguyen, T. T. T., Gooley, G. J., Ingram B. A., Nguyen H. V., Nguyen P. T. and De Silva, S. S. 2009. Current status of farming practices of striped catfish, Pangasianodon hypophthalmus in the Mekong Delta, Vietnam. Aquaculture, 296: 227-236. DOI: 10.1016/j.aqua culture.2009.08.017.

Rahman, A. K. A. 2005. Freshwater fishes of Bangladesh, $2^{\text {nd }}$ edn., Zoological Society of Bangladesh, Dhaka, Bangladesh, xviii +394 pp.

Rahman, M. M. and Verdegem, M. C. J. 2010. Effects of intra- and interspecific competition on diet, growth and behaviour of Labeo calbasu (Hamilton) and Cirrhinus cirrhosus (Bloch). Appl. Anim. Behav. Sci., 128: 103-108. DOI: 10.1016/j.applanim.2010.09.015.

Rahman, M. M., Islam, M. S., Halder, G. C. and Tanaka, M. 2006. Cage culture of sutchi catfish, Pangasius sutchi (Fowler 1937): effects of stocking density on growth, survival, yield and farm profitability. Aquac. Res., 37: 33-39. doi.org/10.1111/j.1365-2109.2005.01390.x.

Rahman, S., Monir, M. S. and Mou, M. H. 2014. Culture potentials of stinging catfish shing (Heteropneustes fossilis) under different stocking densities in northern region of Bangladesh. Trends Fish. Res., 3(2): 11-16.

Razzaque, M. A., Mazid, M. A. Islam, M. N., Kamal, M., Hossain, M. A. and Mansur, M. A. 2003. Influence of stocking density on the culture potential of freshwater catfish Pangasius pangasius in pond. Bangladesh J. Fish. Res., 7(2): 123-130.

Sanches, F. H. C. 2013. Resposta de estresse a substancia de alarme na tilapia-do-nilo. Dissertacao (Mestrado em Zologia) - Instituto de Biociencias de Botucatu, Universidade Estadual Paulista, Botucatu, SP. 28f.

Sanches, L. E. F. and Hayashi, C. 1999. Stocking density effect on Nile tilapia (O. niloticus) fry performance during sex reversal. Acta Seientiarum, 21(3): 619-625.

Sarder, M. R. I. and Mollah, M. F. A. 1991. Stocking density effects on Pangas (Pangasius pangasius Ham.) growth in net cages. Bangladesh J. Fish., 14(1-2): 21-29.

Shaji, A. I. 1995. Freshwater fish diversity in Arlam Wildlife Sanctuary, Kerala, South India. J. Bombay Nat. Hist. Soc., 92: $360-364$

Siddiky, M. N. S. M., Saha, S. B., Mondal, D. K., Ali, A. and Washim, M. R. 2015. Optimisation of stocking density of Mystus gulio (Brackishwater catfish). Int. J. Nat. Soc. Sci., 2: 60-63. 
Siddiqui, K. U., Islam, M. A., Kabir, S. M. H., Ahmed, M., Ahmed, A. T. A., Rahman, A. K. A., Haque, E. U., Ahmed, Z. U., Begum, Z. N. T., Hossain, M. A., Khondker, M. and Rahman, M. M. 2007. Encylopidia of flora and fauna of Bangladesh, vol. 23, Freshwater fishes. Asiatic Society of Bangladesh, Dhaka, 300 pp.

Sogbesan, O. A., Aderolu, Z. A. and Panya, M. W. 2009. Performances of Dutch Clarias juvenile stocked at different densities in out-door happas. World Rural Obser., 1(1): 17-23.

Suleiman, M. A. and Solomon, R. J. 2017. Effect of stocking on the growth and survival of Clarias gariepinus grown in plastic tanks. DRJVMS, 2(3): 82-92.

Suziki, N., Kondo, M., Gunes, E., Ozongun, M. and Ohno, A. 2001. Age and growth of turbot Psetta maxima in the Black Sea. Turk. J. Fish. Aquat. Sci., 1: 43-53.

Talwar, P. K. and Jhingran, A. G. 1991. Inland fishes of India and adjacent countries, vol. $1 \& 2$. Oxford and IBH Publishing Co. Pvt. Ltd., New Delhi, India, 1158 pp.

Taslima, K. and Mollah, M. F. A. 2012. Induced breeding and larvae rearing of critically endangered riverine catfish Rita rita (Hamilton). Asian Fish. Sci., 25: 85-96.

Toko, I., Fiogbe, E. D., Koukpode, B. and Kestemont, P. 2007. Rearing of African catfish (Clarias gariepinus) and vundu catfish (Heterobranchus longifilis) in traditional fish ponds (whedos): effect of stocking density on growth, production and body composition. Aquaculture, 262: 65-72. doi.org/ 10.1016/j.aquaculture.2006.08.054.

Tripathi, S. D. 1996. Present status of breeding and culture of catfishes in South Asia. Aquat. Living Resour., 9: 219-228. doi.org/10.1051/alr:1996056.

Viveen, W. J. A. R., Ritcher, C. J. J., Van Oordti, P. G. W. J., Janssen, J. A. L. and Huisman, E. A. 1985. Practical manual for culture of African catfish C. gariepinus. JointPublication,Directorate of International Cooperation for Foreign Affairs and The Hugue Department of Fish Culture, Netherlands, $13 \mathrm{pp}$.

Watanabe, W. O., Losordo, T. M., Fitzsimmons, K. and Hanley, F. 2002. Tilapia production systems in the Americas: Technological advances, trends and challenges. Rev. Fish. Sci., 10(3-4): 465-498.

Weatherley, A. H. 1976. Factors affecting maximisation of fish growth. J. Fish. Res. Board Can., 22: 1046-1048.

World Bank 2005. Towards sustainable and equitable governance of the global fishing sector, Saving fishes and fishers. The International Bank for Reconstruction and Development. 1818 H. Street, Washington DC, USA. www.worldBank. org/fish.

Yashpal, M., Kumari, U., Mittal, S. and Kumar, A. 2006. Surface architecture of the mouth cavity of a carnivorous fish Rita rita (Hamilton, 1822) (Siluriformes, Bagridae). Belg. J. Zool., 136(2): 155-162. 